https://doi.org/10.17048/AM.2020.179

\title{
Érsek Attila
}

Eszterházy Károly Egyetem NTDI

attilaersek@gmail.com

\section{Történelmi forrásokhoz kapcsolódó kritikai gondolkodásfejlesztés ta- pasztalatai}

\section{Absztrakt}

Az előadás egy átfogó kutatási téma eredményeinek megosztására irányul (Érsek, 2019). Olyan neveléstudományi témában kerestem módszertani megoldást, amely szorosan kapcsolódik a kritikai gondolkodás fejlesztéséhez elektronikus tanulási környezetben. A történelmi tartalomba ágyazott kritikai gondolkodás kognitív elemeinek mérési, fejlesztési területeire koncentráltam. A történelemtanítás kutatásának nemzetközi dimenziójában az egyik megközelítés szerint a kritikai gondolkodás fejlesztésének és a forráselemzésnek kell a történelemtanítás középpontjában állnia (Jancsák, 2019). A feladat és a fogalmi keret összetettsége miatt kevés a sikeresnek tekinthető empirikus vizsgálat a kritikai gondolkodás terén. Magyarországon elindult a fogalom pedagógiai értelmezése (Molnár L., 2002.; Tóth, 2007.; Kovács, 2009.; Fábián, 2014.), az angolszász pedagógia fókuszában a fogalmi tisztázás és a kritikai gondolkodás szerkezeti elemeinek feltárása, összegzése áll (Elder - Paul, 2006.; Lai, 2011). Kutatásom során megalkottam a történelem témakörben alkalmazható kritikai gondolkodás taxonómiát, amelyet pontosítottam Anderson-Krathwohl (2001) tanulási célkitǔzések modelljének segítségével. A történelemtanárok gondolkodását és nézeteit feltártam strukturálatlan kognitív térkép módszerével, támogatott felidézéssel. Szakértői mintavétel történt.

Az oktatástervezési megközelítések közül (Ollé, 2015. p. 86.) a jelen kutatás fejlesztése oktatástanulás szempontjából építette fel a tanköri modulokat, azaz a kognitív folyamatok fejlesztésére koncentrált. A pedagógiai kísérlet terepe a Neo LMS alkalmazás lett, ami e-learning keretrendszer, tananyagtartalom szervező rendszer (LCMS). Általam fejlesztett 2 hetes tanórán kívüli anyagot osztottam meg, tutorként támogattam a diákok tanulási folyamatait. A kutatás eljárásrendjét (eszközök, módszerek), megbízhatósági mutatóit ismertetem az előadás során. A 11-12. évfolyamos gimnazistáknál csoportos valószínűségi mintavételt alkalmaztam, kiegészítettem a hólabda mintavételi eljárással (összesen 330 fö). 
Kutatási kérdés volt: Milyen módon mérhető a történelmi tartalomba ágyazott kritikai gondolkodás kognitív elemeinek tanulói teljesítménye elektronikus tanulási környezetben?

A kutatás hipotézisei közül egyet emelek ki (egymintás t-próbát alkalmaztam ennél): A történelmi tartalomba ágyazott kritikai gondolkodás kognitív elemeinek tanulói teljesítményét lényegesen befolyásolja a Neo LMS fejlesztő anyagainak megismerése. Az önkontrollos csoport esetében ez bizonyítást nyert.

Bízom benne, hogy a tanulók kritikai gondolkodásának kognitív elemeit és a digitális kompetenciát fejlesztő módszertani megoldásom hozzájárul a pedagógiai kultúraváltáshoz. A bemutatásra kerülő pedagógiai kísérlet a tanulók egyéni fejlesztésérére koncentrál, egy jó példája a SAMR modell (Puentedura, 2006) felső szintjének, alkalmazásával hatékonnyá tehető a különböző történelmi források feldolgozása, miközben az IKT által nyújtott lehetőségek is megvalósulnak.

Kulcsszavak: kritikai gondolkodás, Neo LMS, pedagógiai kísérlet, történelem, forrásfeldolgozás

\section{A report on developing critical thinking connected to historical sources}

The goal of the presentation is to share the results of a comprehensive research topic (Érsek, 2019). I attempted to find a skill developing methodological solution in the field of pedagogy that is closely connected to the development of critical thinking in an e-learning environment. The focus is on assessing and developing the cognitive elements of critical thinking embedded in historical teaching materials. One approach to the research on History teaching at an international level states that developing critical thinking and source analysis are the main tasks of History instruction (Jancsák, 2019).

Owing to the complexity of the task and the complex conceptual framework, there has been only a few empirical studies in the field of critical thinking that can be regarded as successful. The pedagogical interpretation of the concept has begun in Hungary (Molnár L., 2002.; Tóth, 2007.; Kovács, 2009.; Fábián, 2014.), and the Anglo-Saxon pedagogy focuses on conceptual clarification and on the exploration and summarization of the structural elements of critical thinking (Elder - Paul, 2006.; Lai, 2011). Based on my research, I created a critical thinking taxonomy which can be applied within the context of History, and I further refined it by using Anderson-Krathwohl's (2001) model of learning objectives. I explored the beliefs and attitudes of History teachers by using a non-structured cognitive map and stimulated recall with questions. The sample procedure was expert sampling.

From the educational planning approaches (Ollé, 2015. p. 86.), the development of the present research created the modules of the course from the education-learning perspective, which means that it focused on the development of cognitive processes. The present pedagogical experiment was 
executed within the Neo LMS application, which is an e-learning platform and a learning content management system (LCMS). I created and shared a two-week skill developing material, which was not part of class activities, with the students, and I assisted their learning processes as a tutor. In this presentation, I outline the research protocol (tools, methods) and reliability indices of the research. I applied probability cluster sampling in the case of eleventh- and twelfth-graders, and additionally used snowball sampling (altogether 330 participants).

The research questions were the following: How can the students' performance be assessed related to the cognitive elements of critical thinking embedded in historical teaching materials in an elearning environment?

I highlight one of the research hypotheses (one-sample t-test was used in this case): Students' performance related to the cognitive aspects of critical thinking embedded in historical teaching materials is significantly influenced by becoming familiar with the Neo LMS skill developing materials. In the case of the single-case experiment group, this hypothesis was confirmed.

I hope that my methodological solution that develops the cognitive elements of students' thinking and their digital competence will contribute to the transition in pedagogical approach. The presented research in the field of pedagogy focuses on the individual development of students, which is a good example of the highest level of the SAMR model (Puentedura, 2006), and by applying this, the interpretation of different historical sources can be more effective and the opportunities offered by the ICT environment are also incorporated.

Key words: critical thinking, Neo LMS, research in pedagogy, history, source analysis

\section{A beválásvizsgálat témája}

A digitális eszközök és módszerek beválásvizsgálata szekcióhoz kapcsolódott a konferencián elhangzott előadásom, amely egy átfogó kutatási téma eredményeinek megosztására irányult (Érsek, 2019). Olyan neveléstudományi témában kerestem módszertani megoldást, amely szorosan kapcsolódik a kritikai gondolkodás fejlesztéséhez elektronikus tanulási környezetben (a történelmi forrásokhoz kapcsolódó kritikai gondolkodásfejlesztés tapasztalatairól beszéltem). Történelmi forrásnak tekintek a történelmi tanulmányok keretei között minden emléket (pl. dokumentum, tárgy), amely a történelmi megismerés kiindulópontja azáltal, hogy abból számunkra hasznosítható információ keletkezik, segítségével a múlt feldolgozható és elemezhető.

A történelmi tartalomba ágyazott kritikai gondolkodás kognitív elemeinek mérési, fejlesztési területeire koncentráltam a kutatás során. A kritikai gondolkodás fejlesztése az amerikai társadalomtudományi nevelés egyik fő feladata, hazánkban az utóbbi évtizedig néhány munka foglalkozott ezzel, disszertációm (A történelmi tartalomba ágyazott kritikai gondolkodás kognitív elemeinek mérési, 
fejlesztési lehetőségei a 11-12. évfolyamos gimnáziumi tanulók körében elektronikus tanulási környezetben) célja e hiányosság pótlása volt.

A köznevelés rendszerében dolgozó középiskolai tanárként tantárgypedagógiai kutatást végeztem, típusa szerint fejlesztésalapú kutatásról van szó. Nem a mérési környezet (Neo LMS) fejlesztése volt a cél, azt eszköznek tekintettem a kutatási kérdések és hipotézisek feltárásához. A feladat és a fogalmi keret összetettsége miatt kevés a sikeresnek tekinthető empirikus vizsgálat a kritikai gondolkodás terén. Magyarországon elindult a fogalom pedagógiai értelmezése (Molnár, 2002.; Tóth, 2007.; Kovács, 2009.; Fábián, 2014.), és az RWCT (Reading and Writing for Critical Thinking) adaptálása módszertani elemeivel segíti a terület fejlesztését. Az angolszász pedagógia fókuszában a fogalmi tisztázás és a kritikai gondolkodás szerkezeti elemeinek feltárása, összegzése áll (Elder - Paul, 2006.; Lai, 2011).

Az elektronikus tanulási környezetek közül kutatásomban a pedagógiai kísérlet terepe a Neo LMS alkalmazás lett. A Neo LMS e-learning keretrendszer, tananyagtartalom szervező rendszer (LCMS). A rendszer nem kötődik tantárgyhoz, csak egy keret, amelyet a tutor tölt ki tartalommal. A pedagógia kísérlet során 2 hetes tanórán kívüli fejlesztő anyagot osztottam meg a témában, támogattam a diákok tanulási folyamatait. Kísérleti és kontrollcsoportokat vontam be, összesen 330 főt.

\section{Kutatási kérdések, hipotézisek}

Kulturális antropológiai megközelítésben az egyén szintjén a sikeresség feltétele az autonómia, ezen belül a tanulásra való képesség (Fábián, 2014, 9-11. o.). A pedagógiai célom a kutatási kísérlet megvalósításával a minőségi, hatékony létezés feltételeinek támogatása, megteremtése volt a gimnázium 11-12. évfolyamos tanulói körében.

A következő kutatási kérdésekre kerestem a választ a tanulói hatékonyság növelése érdekében:

1. Mely változók tekinthetők a történelem tantárgy keretein belül a kritikai gondolkodás kognitív elemeinek?

2. Hogyan fejleszthető hatékonyan a tanuló képessége a történelmi tartalomba ágyazott kritikai gondolkodás kognitív elemeihez kapcsolódóan?

3. Milyen módon mérhető a történelmi tartalomba ágyazott kritikai gondolkodás kognitív elemeinek tanulói teljesítménye elektronikus tanulási környezetben?

A kutatás hipotézisei a következők voltak:

$\mathrm{H}_{1}$ : A kritikai gondolkodás kognitív elemeihez kapcsolódó történelemteszt megoldásának eredményessége függ az előzetes történelmi tudásszinttől. 
$\mathrm{H}_{2}$ : A történelmi tartalomba ágyazott kritikai gondolkodás kognitív elemeinek tanulói teljesítményét lényegesen befolyásolja a Neo LMS fejlesztő anyagainak megismerése.

$\mathrm{H}_{3}$ : Eredményesebb a tanulók tesztmegoldása elektronikus tanulási környezetben a papíralapú teszteknél a történelmi tartalomba ágyazott kritikai gondolkodásának kognitív elemeinek mérése esetében.

$\mathrm{H}_{4}$ : Szignifikáns különbség van az osztályok alapján képzett részminták történelmi tartalomba ágyazott kritikai gondolkodásának kognitív elemei között.

$\mathrm{H}_{5}$ : A fiúk teljesítménye szignifikánsan jobb a történelmi tartalomba ágyazott kritikai gondolkodás kognitív elemeit mérő teszt esetében a lányok eredményénél.

$\mathrm{H}_{6}$ : A történelem tantárgy szeretete erőteljesen meghatározza a történelmi tartalomba ágyazott kritikai gondolkodás kognitív elemeire vonatkozó teszt tanulói eredményét.

$\mathrm{H}_{7}$ : A tanulók történelmi tartalomba ágyazott kritikai gondolkodásának kognitív elemeit nem befolyásolja a szülők iskolai végzettsége.

$\mathrm{H}_{8}$ : A történelem iránt motivált 11-12. osztályos gimnazisták szövegértelmezése hatékony.

\section{A kritikai gondolkodásfejlesztés elméleti keretei}

Az értekezésben az elméleti keretek feltárása során összegeztem a kritikai gondolkodás fogalmával, szerkezetével kapcsolatos álláspontokat, majd a történelmi tartalomba ágyazott forrásfeldolgozáshoz kapcsolódó elemeket tekintettem át. A kritikai gondolkodás meghatározásánál Facione (1990, idézi Lai, 2011) és Halpern (1998, idézi Lai, 2011) fogalmi megközelítését vettem alapul: A kritikai gondolkodás általános kognitív képességek szituációtól függő készlete, olyan céltudatos, önirányított ítéletalkotási és értékelési folyamat, melynek során az egyén kognitív készségeket vagy stratégiákat használ, amelyek növelik a kívánt eredmény, döntés létrejöttének valószínűségét.

Kutatásom során megalkottam a történelem témakörben alkalmazható kritikai gondolkodás taxonómiát:

(1) fogalom azonositása (képi információ, szöveg stb. alapján),

(2) lényegkiemelés (szövegből, képről stb.),

(3) következtetés forrás (szöveges, képi stb.) alapján,

(4) források (szöveges, képi stb.) kritikai elemzése,

(5) források (ábra, szöveg, táblázat, grafikon stb.) értelmezése,

(6) okok, célok feltárása,

(7) érvelés.

A fenti elemeket pontosítottam Anderson-Krathwohl (2001, idézi Heer, 2012) tanulási célkitűzések modelljének segítségével. A kognitív folyamat dimenziói mentén (kategóriák és kognitív folyama- 
tok) azonosítottam a történelmi tartalomba ágyazott kritikai gondolkodás kognitív elemeit, meghatároztam előfordulási arányukat és az operátorokat a gimnáziumi kerettantervben (9-11. évfolyamon) felderítő tartalomelemzéssel. A tartalomelemzéssel nyert adatokat elhelyeztem a kognitív folyamat dimenzió 6 kategóriájának és a tudás dimenzió 4 elemének metszetébe (az 1. táblázat a kognitív elemek arányát mutatja be). A kognitív folyamat dimenziójának kategóriai közül a megértésre, elemzésre és értékelésre vonatkozók emelkednek ki a kerettantervi fejlesztési követelmények (23 darab) esetében a százalékos adatok alapján.

2. táblázat A kritikai gondolkodás folyamatainak történelem tantárgyi kognitív dimenziója (Heer, 2012 alap-

ján) és kerettantervi azonosítása

\begin{tabular}{|c|c|c|c|c|c|}
\hline \multicolumn{6}{|c|}{ Kognitív folyamat dimenzió } \\
\hline ismeret & megértés & alkalmazás & elemzés & értékelés & alkotás \\
\hline $\begin{array}{l}\text { felismerés } \\
\text { vissza- } \\
\text { emlékezés } \\
20 . a^{*}\end{array}$ & $\begin{array}{c}\text { értelmezés } \\
\text { szemléltetés } \\
\text { osztályozás } \\
\text { összefoglalás } \\
\text { következtetés } \\
\text { összehasonlí- } \\
\text { tás } \\
\text { magyarázat } \\
\text { 2., 8., 9., 11., } \\
\text { 12., 18., }\end{array}$ & $\begin{array}{l}\text { végrehajtás } \\
\text { kivitelezés } \\
16 ., 20 . b^{*}\end{array}$ & $\begin{array}{c}\text { megkülönböz- } \\
\text { tetés } \\
\text { rendezés } \\
\text { jellemzés } \\
\text { 1., 5., 10., 14., } \\
\text { 19., 22., } 23 .\end{array}$ & $\begin{array}{c}\text { ellenőrzés } \\
\text { bírálat } \\
\text { 3., 4., 6., } \\
\text { 7., 13., } \\
\text { 17., } 21 .\end{array}$ & $\begin{array}{c}\text { generálás } \\
\text { tervezés } \\
\text { létreho- } \\
\text { zás } \\
15 .\end{array}$ \\
\hline $4,16 \%$ & $25,00 \%$ & $8,33 \%$ & $29,16 \%$ & $29,16 \%$ & $4,16 \%$ \\
\hline
\end{tabular}

A kritikai gondolkodás jelentősége a történelemtanítás során növekedett napjainkban. „A történelemtanítás kutatásának nemzetközi dimenziójában alapvetően két szemléletmód erősödött fel az utóbbi években. Az egyik megközelítés szerint a kritikai gondolkodás fejlesztésének és a forráselemzésnek kell a történelemtanítás krédójában állnia, a másik szerint a történelemtanítás a kollektív emlékezet megőrzője (Jancsák, 2019)." A két álláspont pedagógiai alkalmazásának együttese teremtheti meg az új nemzedékek számára a megfelelő hozzáadott értéket. Önálló, kritikusan gondolkodó emberekké kell válniuk a tanulóknak, ez az egyik alapvető elvárás az iskolákban és a 21. századi készségek között a munkaerőpiacon. A Világgazdasági Fórum 2018-as jelentése alapján a kritikai gondolkodás 2020-ban a második legfontosabb készség, amivel egy munkavállalónak rendelkeznie kell. A 21. századi készségeket állítja a középpontba a "4 C” modell is (Communicate - Kommunikálj! Critically Think - Gondolkodj kritikusan! Collaborate - Müködj együtt! Create - Alkoss!), amely a tanulókat sarkallja innovációra. Ehhez kapcsolódnak a digitális és az alapkészségek. 
Beazonosítottam azokat a kognitív elemeket és szinteket, illetve az ehhez kapcsolódó feladattípusokat, feladatokat, amelyeket felhasználtam a kutatáshoz kapcsolódó papíralapú és elektronikus tesztfeladatokkal történő mérésben.

\section{A kutatás eljárásrendje (mintavétel, eszközök, módszerek)}

Fejlesztésalapú kutatást végeztem, amit a kritikai gondolkodáshoz és az elektronikus tanulási környezethez kapcsolódó feltáró jellegű kutatások előztek meg. A 2018-as tavaszi első mérés (papíralapú előmérés) a 11. osztályos tanulók képességeinek felmérése mellett a mérőeszköz hitelesítésére fókuszált. Így az elektronikus tanulási környezethez kapcsolódó fejlesztési anyagokat ki lehetett dolgozni a megalkotott taxonómiára támaszkodva. Az utómérés megvalósítása a 12. évfolyamon történt.

Csoportos valószínűségi mintavételt alkalmaztam a kísérleti csoportoknál, amelyet a kontrollcsoportok bevonása esetében kiegészítettem a hólabda mintavételi eljárással (létszámok: kísérleti csoport 213 fő a papíralapú mérésnél, a Neo LMS felületén a kísérleti csoport 151 fö, a kontrollcsoport 179 fő). A kísérleti csoportok száma 8, a kontrollcsoportok száma 9 volt. A vizsgálatban résztvevő diákok nemek szerinti megoszlása: 39\% fiú, 61\% lány. A 2. táblázatban foglaltam össze a kutatás eljárásrendjéhez kapcsolódóan a kutatási szakaszokat, eszközöket és módszereket.

2. táblázat A kutatás eszközeinek és módszereinek eljárásrendje

\begin{tabular}{|c|c|c|}
\hline Kutatási szakaszok & Eszközök & Módszerek \\
\hline Kutatási előzmény & & kvantitatív módszerek \\
\hline $\begin{array}{c}2004-2005 \\
\text { A kritikai gondolko- } \\
\text { dás mérése történe- } \\
\text { lemből a } 11 . \text { évfo- } \\
\text { lyamon }\end{array}$ & $\begin{array}{l}\text { papíralapú saját fej- } \\
\text { lesztésű mérőeszközök } \\
\text { történelem tantárgyi } \\
\text { tudásteszt } \\
\text { kritikai gondolkodás } \\
\text { feladatlap tantárgyi } \\
\text { tartalomba ágyazottan } \\
\text { (képességmérés) } \\
\text { adatlap (összehasonlító } \\
\text { vizsgálatokhoz) }\end{array}$ & $\begin{array}{c}\text { feldolgozó módszer: } \\
\text { eredményvizsgálat (teljesít- } \\
\text { ményvizsgálat, kvantitatív } \\
\text { adatelemzés) } \\
\text { kérdőíves felmérés } \\
\text { leíró és matematikai statiszti- } \\
\text { kai módszerek } \\
\text { kétmintás t-próba } \\
\text { korrelációszámítás } \\
\text { klaszteranalízis } \\
\text { varianciaanalízis } \\
\text { regresszióanalízis }\end{array}$ \\
\hline
\end{tabular}




\begin{tabular}{|c|c|c|}
\hline Kutatás & szakirodalom & kombinált modell alkalmazása \\
\hline 2013-tól folyamatos & $\begin{array}{c}\text { elméleti keretek feltárása, } \\
\text { szintetizálása }\end{array}$ \\
\hline $\begin{array}{c}\text { 2013. december } \\
\text { 4 évfolyamos gim- } \\
\text { náziumi kerettan- } \\
\text { terv 1. vizsgálata } \\
\text { (OFI pedagógiai } \\
\text { fejlesztójeként) }\end{array}$ & $\begin{array}{c}\text { 4 évfolyamos gimnázi- } \\
\text { umi kerettanterv }\end{array}$ & $\begin{array}{c}\text { beavatkozásmentes kutatás: } \\
\text { kvalitatív tartalomelemzés }\end{array}$ \\
\hline $\begin{array}{c}\text { 2014 } \\
\text { WEB 2.0 alkalmazá- } \\
\text { sok használata }\end{array}$ & online kérdőívek & mikrokutatások, kvantitatív \\
adatelemzések
\end{tabular}




\begin{tabular}{|c|c|c|}
\hline Fejlesztés szakasza & & $\begin{array}{l}\text { feltáró kombinált modell } \\
\text { iskolajellegű tantárgy- } \\
\text { pedagógiai kutatás }\end{array}$ \\
\hline $\begin{array}{l}\text { 2017/2018. tanév } \\
\text { előtesztelés, fejlesz- } \\
\text { tés, utómérés }\end{array}$ & $\begin{array}{c}\text { a függő változó értéké- } \\
\text { nek mérése (papír ala- } \\
\text { pon) } \\
\text { tudásszint mérése } \\
\text { független változó (NEO } \\
\text { LMS módszertani } \\
\text { anyag - saját fejlesz- } \\
\text { tés) alkalmazása } \\
\text { elektronikus teszttel a } \\
\text { függő változó mérése }\end{array}$ & önkontrollos kísérlet \\
\hline $\begin{array}{l}\text { 2018/2019. tanév } \\
\text { ősze } \\
\text { fejlesztés és utó- } \\
\text { tesztelés } \\
\text { kísérleti és kontroll- } \\
\text { csoportok bevonása }\end{array}$ & $\begin{array}{l}\text { NEO LMS módszertani } \\
\text { anyag módosított vál- } \\
\text { tozata - saját fejlesztés } \\
\text { online kérdőív }\end{array}$ & $\begin{array}{l}\text { kontrollcsoportos kísérlet } \\
\text { háttérváltozók elemzése }\end{array}$ \\
\hline $\begin{array}{l}\text { A kutatási eredmé- } \\
\text { nyek összegzése, } \\
\text { kiegészítése }\end{array}$ & & $\begin{array}{c}\text { kvantitatív és kvalitatív mód- } \\
\text { szerek }\end{array}$ \\
\hline $\begin{array}{c}\text { 2018/2019. tanév } \\
\text { téli és tavaszi idő- } \\
\text { szaka }\end{array}$ & a kutatás adatbázisai & $\begin{array}{c}\text { eredményvizsgálat (teljesít- } \\
\text { ményvizsgálat, kvantitatív } \\
\text { adatelemzés); } \\
\text { háttérváltozók elemzése }\end{array}$ \\
\hline 2019. nyár & $\begin{array}{l}\text { fogalmi térképek készí- } \\
\text { tése: a kritikai gondol- } \\
\text { kodás ismérvei a törté- } \\
\text { nelemtanításban }\end{array}$ & $\begin{array}{l}\text { kvalitatív adatfeldolgozás } \\
\text { (strukturálatlan kognitív tér- } \\
\text { kép módszere támogatott } \\
\text { felidézéssel) }\end{array}$ \\
\hline
\end{tabular}

A kritikai gondolkodással kapcsolatban a történelemtanárok gondolkodását és nézeteit kismintás kutatás keretében tártam fel. A mintavételi eljárás szakértői mintavétellel történt: a kérdezettek gimnáziumban tanító történelemtanárok. Tanári fogalomtérképek készültek a függő változóról: a kritikai gondolkodás ismérvei a történelemtanításban. A legfontosabb kulcsfogalmak, amelyek a kritikai gondolkodással szoros kapcsolatban vannak a kutatás alapján: saját értékelés; önálló, tudatos, reflektív véleményalkotás; rendszerezés, szabályok felismerése és alkotása; forráskritika; problémamegoldás; konceptuális váltás. A kritikai gondolkodás általam legrövidebben megnevezhető szókapcsolatát megerősítette a kutatás: értékelő gondolkodásról van szó, amely a történelemtanítás segítségével, a források feldolgozásával segít eligazodni a jelenkorban. 


\section{A fejlesztésalapú kutatási kísérlet}

Az eredményekből és a szakirodalomból arra lehet következtetni, hogy a tartalomfüggő, konkrét szituációhoz és helyzethez kapcsolódó kritikai gondolkodástanítás felé kell elmozdulni (Molnár L., 2002) a pedagógiai munka során. A Neo LMS felületén elkészített, a fenti témához illeszkedő etananyag kiemelkedő szerepe abban áll, hogy korszerú tanulási környezetben különböző típusú történelmi forrásokhoz kapcsolódó ismeretszerzési módszereiket, technikáikat mélyíthették a tanulók. A tanórákon ezekről tanulnak a diákok, de a fejlesztő felületen összefogottan jelent meg a tájékoztatás. Könnyen befogadható tananyagmennyiséggel és tananyagtartalommal találkoztak. Az információk feldolgozásánál a források kritikai vizsgálata és összevetése fejlett kognitív tevékenységet feltételez, a tanulóknak több szempontú elemzést kellett végezniük a feldolgozás során, ezt támogatta az elkészített tananyag.

A Neo LMS felületére készített fejlesztő anyag a történelmi források feldolgozásának, a feldolgozás hatékonyságának, tudatos múveleti eljárásainak támogatására készült. A tanórán kívüli tanulást támogató anyagként az adott témakörben modulokba szervezett a feldolgozandó anyag (külön ütemben és tankörben az önkontrollos, a kísérleti és kontrollcsoportoknak). Minden csoport külön kapott tájékoztatást a felületre történő belépés módjáról, a felület használatáról és a tematika ütemezéséről.

A belépés ütemezése a tanulókra volt bízva egy adott időszakban, hisz tanórán kívüli tanulási segédlet készült, amely a diákok számára napi 20 perces elfoglaltságot jelentett átlagosan. A történelem tantárgyhoz tartozó követelményeket a fejlesztési folyamat során középpontba állítottam, ezek ismeretében a tanítási-tanulási folyamatot szakszerűen, az elsajátítandó tananyagtartalmat támogatva szerveztem. A cél- és követelményrendszer ismertetésével nem terheltem a diákokat, a felület használatát, a témában az elmélyülést nem támogatta volna. A tankör teljes tematikai struktúráját láthatták a DFG tankörének felületén, de a továbbhaladás a tartalomban akkor vált lehetségessé a tanulók számára, amikor egy kijelölt és kitúzött modult elsajátítottak. A modulokat (foglalkozásokat, fejezeteket) csak sorrendben lehetett teljesíteni. A kialakított szerkezet a programozott tanulás elemeit is felhasználta. A struktúrát a későbbiekben is lehetett használni vizuálisan áttekinthető összefoglalásként.

A NAT (ez nem azonos a 2020 szeptemberében életbe lépett szabályozással) nevelési-fejlesztési céljai közül kiemelt terület volt a tanulás tanulásának támogatása. A kulcskompetenciák közül a következő elemekre fókuszált a fejlesztés: anyanyelvi kommunikáció, digitális kompetencia és a hatékony, önálló tanulás. A 4 évfolyamos gimnáziumi kerettanterv fejlesztési követelményeire támaszkodott az e-learning tananyag. A diákok képességfejlesztésének támogatása a célok között szerepelt: 
ismeretszerzés, források használata; a szaknyelv alkalmazása; tájékozódás térben és időben; kiemelt terület volt a kritikai gondolkodás kognitív elemeire vonatkozó folyamatok fejlesztése. Az ismeretbővítés része volt néhány kötelező adatot tartalmazó szöveg, kép, feladat felhasználása (fogalom, topográfia, kronológia, személy), beépítése. Eszközhasználatban jellemző volt a mobileszközök túlsúlya, ez volt a fejlesztői javaslat is. Igazodva a kutatási célokhoz a munkaformák közül az egyéni munkát támogatta a felület, kommunikációra a diák-tutor között került sor szükség esetén. Formatív értékelési szempontok érvényesültek (Lengyelné, 2011), erre automatikus visszajelzést állítottam be a felületen, és szöveges értékelést is alkalmaztam.

A Neo LMS felületén célzottan és tematikusan, forrásfajták szerint történt a fejlesztési anyag kidolgozása. A NEO LMS rendszerben történő tananyagfejlesztést és a hozzá kapcsolódó kimeneti etesztfeladatok létrehozását papíralapú mérés előzte meg a történelmi tartalomba ágyazott kritikai gondolkodás kognitív elemeire vonatkozóan. A mérési adataim bizonyítják, bár nincs mérési protokollja a kritikai gondolkodásbeli kognitív elemek mérésének történelemből, lehetségessé vált a fejlesztő tankör kidolgozása a papíralapú mérések megbízhatósági mutatói és a megfelelő mennyiségű mintaelemszámra támaszkodó kutatási következtetések alapján. A kutatás megbízhatóságát (3. táblázat) a mérőeszközök reliabilitásmutatója alapján határoztam meg. A 2018-as feladatsor mérési eredményeire, taxonómiájára és feladattípusaira támaszkodva lehetővé vált történelem tartalmon keresztül a kritikai gondolkodás kognitív elemeihez kapcsolódó fejlesztő anyag kidolgozása, ezt követően pedig a kimeneti e-teszt létrehozása.

3. táblázat. A feladatlapok reliabilitásmutatói (Cronbach- $\alpha$ )

\begin{tabular}{|c|c|c|}
\hline Feladatlapok & $\begin{array}{c}\text { Önkontrollos } \\
\text { mérés (2018) }\end{array}$ & $\begin{array}{c}\text { Mérés } \\
(2018)\end{array}$ \\
\hline Történelem (ismeret) & 0,94 & - \\
\hline $\begin{array}{c}\text { Kritikai gondolkodás } \\
\text { kognitív elemei }\end{array}$ & 0,81 & 0,83 \\
\hline
\end{tabular}

A tematika 10 modulból állt, amelyet a kimeneti e-teszt zárt 11. elemként. Az e-teszt önkontrollos mérésekor megbízhatónak bizonyult a feladatsor (Cronbach- $\alpha=0,77$ ), de a 330 fős (kísérleti és kontrollcsoport) mérés alapján éppen elfogadható a feladatsor megbízhatósága (Cronbach- $\alpha=0,69$ ). Volt olyan csoport is, ahol az átlagosnál megbízhatóbban mért az e-teszt (Cronbach- $\alpha=0,85$ ).

A tanórán kívüli tevékenység témái (A forrásfeldolgozásokhoz az alapvető módszertani segédlet Kaposi-Szabó (2017) által készített anyag volt, illetve Tóth (2007) könyve.):

1. Bevezetés

2. Logikai játék, érvelés

3. Szöveges források feldolgozása I. 
4. Szöveges források feldolgozása II.

5. Képi források (pl. fényképek, festmények) feldolgozása I.

6. Képi források (pl. karikatúrák, plakátok) feldolgozása II.

7. Térképek feldolgozása, „olvasása”

8. A képregények feldolgozása

9. A filmek megértésének technikái

10. Grafikonok, táblázatok feldolgozása

11. Órai kimeneti tesztsor

A 2. modul egy részét (Logikai játék, érvelés) mutatom be. Két fejezetből áll a modul: Következtetés és megértés ("játék" a nyelvvel - oldal); Fejtörő (teszt). A tankör egyik legnehezebben feldolgozható része ez az összeállított elméleti anyag mennyisége és mélysége miatt. Külön fájl támogatta a feldolgozást az érvelésről: A tanulók figyelmét ráirányította arra, hogy mi tekinthető helyes érvelésnek, melyek a részei. Tudatosítani kívánta ez a rész, hogy mindennapi életünk során ritkán fordul elő, hogy az alapállítás mindkét részét kimondjuk, mert az egyik premissza kimondására általában nincs szükség. Kitér a modul az érvelési hibákra, típusaira és a racionális érvelés 10 alapvető szabályára, megsértésük módjára.

A fejlesztendő, szükséges kognitív tevékenységek tudatosításának érdekében az elméleti rész felhívja arra a figyelmet röviden, hogy a kritikai gondolkodás alapvető megértési eleme az olvasás képességén alapul, amelyhez szükséges a nyelvi megértés (a beszéd megértésének képessége) és a dekódolás (az írott információ felismerése és feldolgozása). A nyelvi megértés legegyszerübb formája az explicit megértés, amikor a hallottak közvetlen jelentését értjük meg. Másik formája az értelmezés, amely következtetésen alapul. A következtetés megértéséhez nélkülözhetetlen a kontextus (szövegösszefüggés, szövegkörnyezet). Ennek az elméleti résznek a gyakorlati megvalósítása a játékosításhoz kapcsolódó fejtörővel zárja a modult. Előtte azonban egy gyakorlati példával szemléltet, hogy a megértési folyamatot támogassa. Az alábbi példa (Tóth, 2007 alapján) utal a fejezet címére (következtetés és megértés) és a kognitív tevékenység fontosságára:

Játék a nyelvvel!

A következő az állítás:

„A képviselő bevallotta, hogy övé az a fegyver, ami kioltotta a felesége életét."

Milyen jelentéseket lehet elemi állításként a mondathoz kapcsolni, ha gondolkodunk? Előbb gondolkozzon önállóan! Mire következtet? 
- Van egy képviselő.

- Van fegyvere.

- A képviselő nős ember.

- A felesége halott.

- A fegyver okozta a halálát.

- A fegyver a képviselőé.

- A képviselő bevallotta, hogy a fegyver az övé.

Egyéb következtetések, kérdések:

- Egy ismert ember búnténybe keveredett.

- A fegyvert megtalálták.

- A fegyver pisztoly? Esetleg puska? Vagy kés? Nagyobb fegyverek valószínútlenek ebben a helyzetben.

- A képviselő ölte meg? Ez az állításból nem feltétlenül következik.

- Lehetett öngyilkos a felesége?

- Esetleg gyilkosság áldozata? Lelőtték, leütötték vagy leszúrták?

- Esetleg véletlen baleset volt?

- Megalapozottak a következtetések? A képviselő biztos, hogy az igazat vallotta?

TEHÁT: A következtetések lehetnek alaptalanok, nem lehet egyedüli igazságként felfogni. Gondolni kell arra, hogy lehetnek más értelmezések is!

A tanuló számára a fenti példa tudatosítja, hogy nem szabad egy lehetséges megoldást keresnie az igazságkeresés során, és ezt kell alkalmazni a történelmi források feldolgozása esetében is. A 4. táblázat tartalmazza az e-teszt feladatainak típusát és az eredményeket. 
4. táblázat. Az e-teszt feladatainak kognitív és tematikus azonosítása, eredmények

\begin{tabular}{|c|c|c|}
\hline Feladatok & $\begin{array}{c}\text { Kísérleti csoport } \\
\mathrm{N}=151 \\
\%\end{array}$ & $\begin{array}{c}\text { Kontrollcsoport } \\
\mathrm{N}=179 \\
\%\end{array}$ \\
\hline 1. Értékelés (érvelés) & 28,48 & $\underline{36,87}$ \\
\hline 2. Elemzés (karikatúra) & $\underline{36,20}$ & 35,20 \\
\hline 3. Értékelés (Teleki) & $\underline{65,56}$ & 63,13 \\
\hline $\begin{array}{c}\text { 4. Relációanalízis (Pragmatica Sanc- } \\
\text { tio) }\end{array}$ & $\underline{52,32}$ & 50,84 \\
\hline 5. Képelemzés (I. világháború) & 30,02 & $\underline{32,22}$ \\
\hline 6. Grafikon elemzése (kivándorlás) & 33,77 & $\underline{36,87}$ \\
\hline 7. Alkalmazás (titkos jegyzőkönyv) & $\underline{41,85}$ & $\underline{40,87}$ \\
\hline 8. Értékelés (Húsvéti cikk) & 45,30 & $\underline{48,16}$ \\
\hline 9. Elemzés (Klebelsberg) & 29,80 & $\underline{35,89}$ \\
\hline 10. Értékelés (gazdasági világválság) & $\underline{46,36}$ & 42,09 \\
\hline 11. Értékelés (Lincoln - karikatúra) & 56,95 & $\underline{62,57}$ \\
\hline 12. Alkotás (térkép) & 18,54 & $\underline{26,26}$ \\
\hline
\end{tabular}

A kísérleti csoportok 5, a kontrollcsoportok 7 feladatban teljesítettek jobban. A legkevésbé sikeres az alkotás szintű feladat (szövegalkotás térkép alapján) megoldása volt.

\section{Kutatási eredmények}

A digitális eszközhasználattal megvalósítható lehetőségek és feladatok motiválók lehetnek a diákok számára, de a tanári szemléletmód megváltoztatása nélkül elképzelhetetlen e terület fejlesztése. Bízom benne, hogy a tanulók kritikai gondolkodásának kognitív elemeit és a digitális kompetenciát fejlesztő módszertani lehetőségeket kombináló megoldásom hozzájárul a pedagógiai kultúraváltáshoz. Pedagógiai kísérletem azt kutatta, hogy milyen megismerési elemek, technikák alkalmazásával tehető hatékonnyá a különböző típusú történelmi források feldolgozása. A kognitív elemekről, gondolkodási folyamatokról konkrét algoritmusokat kínál a fejlesztő tankör a hatékonyság növelésének érdekében.

Célom volt a pedagógiai eredményesség növelése érdekében a diákok tevékenykedtetése. Az eredmények tükrében állítható, hogy a kritikai gondolkodás kognitív elemeinek fejlesztésére több időt kell szánni tanórákon is.

A kutatási folyamat során különböző módszertani eljárásokkal bizonyítottam vagy cáfoltam a hipotéziseket:

$\mathrm{H}_{1}$ : A kritikai gondolkodás kognitív elemeihez kapcsolódó történelemteszt megoldásának eredményessége függ az előzetes történelmi tudásszinttől. 
A történelem tesztfeladatokkal ismeretjellegű információk szummatív mérése történt az önkontrollos csoport esetében. A történelmi ismeretek mérése tette lehetővé az ismeretekre és képességekre vonatkozó eredmények összehasonlító vizsgálatát. A minta esetében legszorosabb a kapcsolat a történelmi ismeret és a kritikai gondolkodás kognitív elemeit mérő feladatlap eredményei között. Erős, pozitív irányú kapcsolatról van szó, amely alapján a történelmi ismeretek nagysága 75\%-ban meghatározta a történelmi tartalomba ágyazott kritikai gondolkodás kognitív elemeinek fejlettségi szintjét. A parciális korrelációs együttható kiszámításával kiszűrhető volt a történelem szeretetének hatása $(0,67)$. Így tehát a történelmi tartalomba ágyazott kritikai gondolkodás kognitív elemeinek fejlettségét a történelmi ismeretek nagysága 67\%-ban határozta meg 99\%-os valószínúséggel az adott mintán.

A hipotézis bizonyításra került.

Az eredmény alapján így fogalmazható meg az 1. tézis: A tanulók történelmi tudásszintje jelentősen meghatározza a kritikai gondolkodás kognitív elemeihez kapcsolódó történelemteszt megoldásának eredményességét.

$\mathrm{H}_{2}$ : A történelmi tartalomba ágyazott kritikai gondolkodás kognitív elemeinek tanulói teljesítményét lényegesen befolyásolja a Neo LMS fejlesztő anyagainak megismerése.

Feltételeztem, hogy a Neo LMS fejlesztő anyagok megismerése és az IKT eszközök pedagógiai célú használata segítségével fejlődés történik a diákok kritikai gondolkodás kognitív elemeihez kapcsolódó teljesítményében. A kísérleti csoportok papíralapú és e-teszt eredményeit összehasonlítva kiderült, hogy több csoport esetében valóban van fejlődés a korábbi teljesítményhez képest, de 2 csoport eredménye kisebb mértékben elmarad az előző mérés teljesítményétől. Az egymintás t-próba alapján az önkontrollos csoport eredményéről 95\%-os szignifikanciaszinten állítható, hogy nem a véletlennek köszönhető a különbség: a Neo LMS fejlesztő anyagának hatása volt az eredményeikre. Az önkontrollos csoport esetében bizonyítást nyert, hogy a fejlesztő tankörnek szignifikáns hatása volt az eredményeikre.

Az önkontrollos csoport esetében bizonyítást nyert a hipotézis.

A többi csoport esetében azonban nem szignifikáns a különbség: a papíralapú teszt eredménye csupán 21\%-ban befolyásolja a Neo LMS fejlesztő anyagait átnéző kísérleti csoportok eredményét. A fenti következtetés helyességét regresszióanalízissel is vizsgáltam, ez is megerősíti a hipotézis elvetését a többi kísérleti csoport esetében.

Ennek következtében a hipotézist nem tekinthetjük bizonyítottnak. 
$\mathrm{H}_{3}$ : Eredményesebb a tanulók tesztmegoldása elektronikus tanulási környezetben a papíralapú teszteknél a történelmi tartalomba ágyazott kritikai gondolkodásának kognitív elemeinek mérése esetében.

A kritikai gondolkodás kognitív elemeit mérő történelmi e-teszt eredményével mint függő változóval végzett regresszióanalízis adatai alapján nem nyert megerősítést a hipotézis. A hipotézis a kísérleti csoportok által nyújtott teljesítmények alapján nem állítható teljes bizonyossággal. Eredményesebb a tanulók többsége a korábbiaknál, de nem bír jelentős magyarázóerővel.

A hipotézis nem igazolódott.

$\mathrm{H}_{4}$ : Szignifikáns különbség van az osztályok alapján képzett részminták történelmi tartalomba ágyazott kritikai gondolkodásának kognitív elemei között.

A különbséget látszott igazolni az, hogy voltak eltérések az osztályok teljesítményének átlagértékei között. Azt azonban, hogy ezek az átlagok valóban, azaz szignifikánsan különböznek-e egymástól, varianciaanalízissel igazoltam, mivel kettőnél több egydimenziós minta volt. Feltételeztem, hogy a különböző minták ugyanabból a populációból valók, vagyis a minták homogének. Az F érték alapján kijelenthető, hogy a csoportok ugyanahhoz a populációhoz tartozónak tekinthetők (99,99\%).

A varianciaanalízis eredményei azt mutatták, hogy van legalább egy (több is) olyan csoport a mintában, amelyik átlaga különbözik a többitől. A mintáról páronként el lehetett dönteni a Tukey-próba segítségével, hogy melyek különböznek $(p<0,05)$.

A hipotézis bizonyításra került.

Az eredmény alapján így fogalmazható meg a 2. tézis: A történelmi tartalomba ágyazott kritikai gondolkodás kognitív elemeinek mérése során szignifikáns különbséget lehet kimutatni az osztályok alapján képzett részminták teljesítménye között.

A 2. tézissel kapcsolatban további kutatási feladat lehet annak vizsgálata, hogy az ismeretek mélységén kívül (lásd 1. tézis) mely változók okozzák ezt a különbséget.

$H_{5}$ : A fiúk teljesítménye szignifikánsan jobb a történelmi tartalomba ágyazott kritikai gondolkodás kognitív elemeit mérő teszt esetében a lányok eredményénél.

$A z$ önkontrollos csoport történelmi ismereteinek feladatlapjánál a fiúk teljesítménye szignifikánsan jobb volt a lányokénál 99,9\%-os valószínűséggel (a fiúk létszáma 10, a lányoké 17 fő). Ez nem a véletlennek volt köszönhető az adatok alapján, azaz a történelmi ismeretek területén az adott mintán a fiúk szignifikánsan jobban teljesítettek. Mivel a történelmi ismeret jelentős magyarázó erővel bír a kritikai gondolkodás kognitív elemeire vonatkozó teljesítmény eredményessége területén, ezért feltételeztem a fenti állítást. 
A fiúk és lányok teljesítménye közötti különbséget kétmintás t-próbával mutattam ki. A vizsgált mintában a fiúk létszáma 76 fő (39\%), a lányoké 118 fő (61\%). A hipotézist a vizsgálat alapján el kell vetni. A Levene-teszt alapján a két minta varianciája egyenlőnek tekinthető a történelmi tartalomba ágyazott kritikai gondolkodás kognitív elemeinek használata területén (85,4\%-os valószínúséggel). A lányok teljesítményének százalékos átlaga jobb 1,56\%-kal, de nem szignifikáns az eltérés a két minta között a papíralapú teszt esetében, azaz a közöttük levő különbség nagy valószínúséggel a véletlennek köszönhető.

A kísérleti csoportokban a papíralapú tesztnél a hipotézis nem igazolódott.

Az e-teszt esetében azonban bizonyítást nyert, hogy a két minta közötti különbség nem a véletlennek köszönhető. A fiúk létszáma 54, a lányoké 97 fő volt az e-teszt esetében. A Levene-teszt alapján a két minta varianciája egyenlőnek tekinthető a történelmi tartalomba ágyazott kritikai gondolkodás kognitív elemeinek használata területén az e-tesztnél, így a kétmintás t-próba elvégezhető volt. Az értékek alapján 97\%-os szignifikanciaszinten kijelenhetjük, hogy a fiúk jobb teljesítményt nyújtanak a történelmi tartalomba ágyazott kritikai gondolkodás kognitív elemeit mérő e-teszt esetében a lányoknál.

A hipotézis igazolódott.

Az eredmény alapján így fogalmazható meg a 3. tézis: A történelmi tartalomba ágyazott kritikai gondolkodás kognitív elemeit mérő elektronikus teszteken a fiúk teljesítménye jelentős mértékben jobb a lányok eredményénél.

$\mathrm{H}_{6}$ : A történelem tantárgy szeretete erőteljesen meghatározza a történelmi tartalomba ágyazott kritikai gondolkodás kognitív elemeire vonatkozó teszt tanulói eredményét.

A korrelációs együtthatók mértéke és szignifikanciája alapján a történelem tantárgy szeretete nem határozza meg a történelmi tartalomba ágyazott kritikai gondolkodás kognitív elemeinek tanulói eredményét jelentős mértékben (21\% a magyarázó ereje). A regressziós elemzés ezt tovább árnyalta, a történelem tantárgy szeretete kevésbé bírt meghatározó erővel: a történelmi tartalomba ágyazott kritikai gondolkodás kognitív elemeinek tanulói teljesítményéhez csupán 4\%-ban járult hozzá az elemzés alapján.

A hipotézist el kellett vetni 99,9\%-os valószínúséggel.

$\mathrm{H}_{7}$ : A tanulók történelmi tartalomba ágyazott kritikai gondolkodásának kognitív elemeit nem befolyásolja a szülők iskolai végzettsége. 
Elvégeztem a regressziós elemzést (a történelmi tartalomba ágyazott kritikai gondolkodás kognitív elemeit mérő teszt eredményével mint függő változóval végzett regresszióanalízis). A szülői iskolai végzettségnek nincs magyarázó ereje a történelmi tartalomba ágyazott kritikai gondolkodás kognitív elemeire vonatkozó teszt tanulói teljesítményére a vizsgált minta esetében. Nem befolyásolja a tanulói teljesítményt a szülők iskolai végzettsége, 4\%-át magyarázza az eredményeknek.

A hipotézis igazolódott.

Az eredmény alapján így fogalmazható meg a 4. tézis: A szülők iskolai végzettsége szignifikánsan nem befolyásolja a történelmi tartalomba ágyazott kritikai gondolkodás kognitív elemeire vonatkozó mérés tanulói teljesítményét.

$\mathrm{H}_{8}$ : A történelem iránt motivált 11-12. osztályos gimnazisták szövegértelmezése hatékony. A hipotézist a háttéradatok birtokában a motivációhoz kapcsolódó adatok (történelmi attitűd, történelmi könyvek olvasása, történelemjegy) és a szöveges feladatok (az e-teszt 7-9. feladatai) kapcsolatával vizsgáltam. A történelmi tartalomba ágyazott kritikai gondolkodás kognitív elemeit mérő e-teszt szöveges feladatait függő változónak tekintve elvégeztem a regresszióanalízist, valamint ellenőrzésként a korrelációs kapcsolat vizsgálatát is: gyenge pozitív együtt járás állapítható meg, de az adatok alapján a hipotézis nem igazolódott.

El kell vetni a hipotézist.

A köznevelés és kutatás területén hiánypótló eredmények, az empirikus és kvalitatív kutatási következtetések, amelyeket a disszertáció bemutat, további kutatások kiindulópontja lehet. A további kutatási lehetőségek egyike, hogy a fejlesztéshez készített Neo LMS anyagot blended learning jellegű módszertani anyaggá lehet alakítani. Órai támogatással kell elvégezni a fejlesztést, ennek hatékonyságát össze kell vetni a jelenlegi kutatási adatokkal. Az egyik kísérleti csoport esetében ez a módszer hatékonynak bizonyult. Az ő fejlődési eredményük jobb a kísérleti csoportok átlagos teljesítményétől. Javasolt kutatási kérdés: Szignifikánsan tudja-e növelni a tanulók kritikai gondolkodásának kognitív elemeit a blended learning módszertani megoldás fejlesztési anyaga?

A kutatásalapú vagy problémaorientált tanulási folyamat fejleszti leginkább a gondolkodási folyamatokat, meggyőződésem és kutatásaim szerint a vizsgált módszertani elemek közül ezek a leghatékonyabbak. A projektek megoldása, csoportos feldolgozása hozzájárul a tanulók 21. századi készségeinek fejlesztéséhez. E területen végzett hatékonyságvizsgálat elemeinek kidolgozása, mérése és fejlesztése elektronikus tanulási környezetben segítené a digitális átállást. Javasolt kutatási kérdés: Milyen kvantitatív és kvalitatív kutatási módszereket lehet párosítani a javasolt hatékonyságvizsgálathoz? 


\section{Irodalomjegyzék}

Anderson, L.W. (Ed.), Krathwohl, D.R. (Ed.), Airasian, P.W. Cruikshank, K.A., Mayer, R.E., Pintrich, P.R., Raths, J., \& Wittrock, M.C. (2001): A taxonomy for learning, teaching, and assessing: A revision of Bloom's Taxonomy of Educational Objectives (Complete edition). New York: Longman. lowa State University CELT 2017. A Model of Learning Objectives. URL: https://bit.ly/1VfUhn2 (2020. 10. 31.); idézi Heer, R. 2012.

Elder - Paul (2006): Critical Thinking. Concepts and Tools. URL: https://bit.ly/2kEBJUH (2019. 09. 23.)

Érsek (2019): A történelmi tartalomba ágyazott kritikai gondolkodás kognitív elemeinek mérési, fejlesztési lehetőségei a 11-12. évfolyamos gimnáziumi tanulók körében elektronikus tanulási környezetben. Doktori értekezés, EKE http://disszertacio.uni-eszterhazy.hu/76/ (2020. 10. 07.)

Fábián Gyöngyi (2014): Kritikai gondolkodás az osztályteremben. Gondolat Kiadó, Budapest.

Főző Attila László (2016): SAMR-létra. K.O.M.P.O.S.Z.T URL: https://bit.ly/2mfCbc9 (2020. 10. 31.)

Jákó Katalin (2009): A kritikai gondolkodás. In: Kovács Zoltán (szerk.): A kritikai gondolkodás fejlesztése. Módszertani segédlet. Kolozsvári Egyetemi Kiadó, Kolozsvár. pp. 9-41.

Jancsák Csaba (2019): Kutatási tényeken alapuló tananyagfejlesztés az MTA-SZTE Elbeszélt Történelem és Történelemtanítás Kutatócsoportban. Félidős szakmai beszámoló. MTA, URL: https://bit.ly/2U1KHee (2020. 10. 31.)

Kaposi József - Szabó Márta (2017): Módszerek a források feldolgozásához. URL: https://bit.ly/2nh534x (2020. 10. 31.) - Egyéb/A források feldolgozása.

Komenczi Bertalan (2009): Elektronikus tanulási környezetek. Gondolat Kiadó, Budapest.

Kovács Zoltán (szerk.) (2009): A kritikai gondolkodás fejlesztése. Módszertani segédlet. Kolozsvári Egyetemi Kiadó, Kolozsvár.

Lai, Emily R. (2011): Critical Thinking and Pedagogy: Critical Thinking in Literary Studies. URL: http://bit.ly/2ndhtYm (2020. 10. 31.)

Lengyelné, Molnár Tünde (2011): A pedagógiai mérés és értékelés feladataira való felkészítés az árnyalt tanulói értékelés módszertanának tükrében. In: Estefánné, Varga Magdolna (szerk.) Megújuló tananyagtartalmak, módszerek a kompetencialapú tanárképzésben. Eger, Magyarország : Eszterházy Károly Főiskola (EKF) (2011) 122 p. pp. 83-105.

Lengyelné, Molnár Tünde (2009): Hallgatói kérdőív elemzése. In: Kis-Tóth, Lajos (szerk.) Elektronikus tanulási környezetek kialakítása I., Eger, Magyarország : Líceum Kiadó, pp. 52-63.

Molnár László (2002): A kritikai gondolkodás. In: Csapó Benő (szerk.): Az iskolai múveltség, Osiris Kiadó, Budapest. pp. 217-237. 
Ollé János - Kocsis Ágnes - Molnár Előd - Sablik Henrik - Pápai Anna - Faragó Boglárka (2015): Oktatástervezés, digitális tartalomfejlesztés. Líceum Kiadó, Eger. URL: https://bit.ly/2HqQ1jQ (2020. 10. 31.)

Puentedura, R. (2006): Transformation, Technology, and Education. URL: $\underline{\text { https://bit.ly/2laTQ4S }}$ (2020. 10. 31.)

Sántha Kálmán (2007): Kvalitatív módszerek alkalmazása a reflektív gondolkodás feltárásában. In. Falus Iván (szerk.): A tanárrá válás folyamata. Gondolat Kiadó, Budapest pp. 177-243.

Sántha Kálmán (2009): Bevezetés a kvalitatív pedagógiai kutatás módszertanába. Eötvös József Könyvkiadó, Budapest.

Tóth László (2007): Kritikai olvasás. Kritikai gondolkodás. Pedellus Könyvkiadó, Debrecen.

Vajda Barnabás (2018): Bevezetés a történelemdidaktikába és a történelemmetodikába. Második kiadás. Selye János Egyetem Tanárképző Kar, Komárom. 